\title{
Caries behavior in deciduous dentition and fluoridated water
}

\begin{abstract}
Background: There is no evidence that fluoridation of public water supplies generates a preventive benefit in relation to dental caries, to those provided by the widespread use of fluoridated dentifrices; especially on the deciduous dentition, a current challenge in the field of Oral Health in the regions of the Americas and the Caribbean.
\end{abstract}

Objectives: To analyze the degree of the preventive benefit of exposure to fluoridated water in relation to caries in the deciduous dentition.

Methods: A double census population survey was conducted in two Brazilian cities, in 5 and 6years old children $(\mathrm{N}=233)$, immersed in their exposure (Silveiras, $\mathrm{N}=149$ ) or not exposure (São José do Barreiro, N= 84) condition to fluoridated water, from 2009 to 2014 . The experience, magnitude and degree of caries polarization were evaluated using the dmft index and the association was tested using Pearson's chi-square statistics and prevalence ratio (PR) between not exposed (NE) and exposed (E).

Results and discussion: Although caries experience $(\mathrm{dmft} \geq 1)$ was not associated with exposure to fluoridated water (chi-square $=2.77, \mathrm{p}=0.96, \alpha=5 \%$ ), there was a significant difference in the magnitude which the disease reached the population: the mean $\mathrm{dmft}$ were 2.74 in those exposed and 4.17 in those not exposed. The degree of polarization, indicated by the percentage of individuals with $\mathrm{dmft}=0$, was different, being higher $(43.0 \%)$ in those exposed and lower $(31.0 \%)$ in those not exposed. PR (NE/E) was 1.21 indicating that exposure to fluoridated water corresponded to a $21 \%$ lower prevalence rate, compared to those not exposed.

Conclusion: Exposure to fluoridated water implied a lower mean value of the $\mathrm{dmft}$ index, even in the presence of the concomitant exposure to fluoridated dentifrice.

Keywords: public health, oral health, dental caries, fluoridation, primary dentition
Volume 7 Issue 4 - 2018

\section{Mariângela Guanaes Bortolo da Cruz, Paulo Capel Narvai}

Department of Politics, São Paulo University, Brazil

Correspondence: Mariângela Guanaes Bortolo da Cruz, Department of Politics, Management and Health of Public Health College of São Paulo University, Rua Roquete Pinto 313, Butantã, São Paulo, CEP 05515 010, Brazil,Tel +55-II-9-92796898,Email mariandre94@live.com

Received: April 21, 2018 | Published: July 06, 2018

\section{Introduction}

Caries is a disease of complex etiopathogenesis resulting from multiple risk factors. With an unequal prevalence in populations, it is not only the result of biological variations derived from the parasitehost relationship, but also from the social differences between people. Is still considered the greatest challenge of Oral Health. ${ }^{1-4}$ Untreated caries in deciduous dentition is one of the ten most prevalent pathological conditions in children, affecting around 600 million, in $2010 .^{5}$ Significant reductions have been found in the prevalence and severity of dental caries in school-aged children in industrialized countries. ${ }^{6,7}$ But, in England, Wales and Arab Emirates, studies pointed out that proportion of untreated caries in the deciduous relative to the permanents is higher in poor communities, mainly where children are not exposed to fluoridation of public water supply.$^{6-8}$ In the metaanalysis that included 75 studies on the prevalence of caries in Latin America (including Brazil) and the Caribbean, since the beginning of the $21^{\text {st }}$ century, it was found that more than $50 \%$ of children aged 5 and 6 years are affected by the disease. ${ }^{9}$ Caries in primary teeth has remained a major public oral health challenge in these American regions. In addition to the known risk factors represented by a diet rich in sugars, poor oral hygiene, low maternal schooling and poverty, the familiar perception of the transience of this dentition is added. ${ }^{10-12}$

The Brazilian context demonstrated by the last National Oral Health Survey, conducted in 2010, pointed out eight of ten decayed deciduous teeth are not treated. Therefore, effective protective measures in the prevention of the disease have extreme health relevance. ${ }^{10-13}$ In 1998 , in Blumenau, municipality of southern Brazil, significant differences were found in the prevalence and severity of caries in schoolchildren aged 6 to 12 years, when comparing students who attend public and private schools. Private school students had better oral conditions. ${ }^{10,11}$ In 2006, when studying the individual and contextual determinants of the need for dental treatment in the deciduous dentition in Brazil, using the 2003 National Oral Health Survey, it was found that black children, rural dweller and public school students possessed the highest percentages of untreated decayed deciduous teeth. ${ }^{12,13}$ These searches show that also in Brazil, health conditions, poor oral health status and need for dental treatment are closely associated with the socioeconomic context in which people are inserted. ${ }^{14-16}$

The discovery of the preventive effect of fluoride made it, throughout the $20^{\text {th }}$ century, the main agent used in coping with dental caries. Fluoride dentifrices, widely marketed since the end of the $1980^{\text {s }}$, as well as the fluoridation of water supply, which has been compulsory since 1974, stand out as the main preventive methods used against the disease in Brazil. ${ }^{17-19}$ Given the proven preventive efficacy of fluoridated dentifrices, there is an interest in examining whether, in contexts where the use of such products is widespread, the preventive efficacy of fluoridation of public supply water remains or whether, on the contrary, neutralized or reduced to insignificant levels. ${ }^{20-22}$ The objective of the present study was to verify in two small municipalities of the Southeast region of Brazil, whose populations have universal access to fluoridated dentifrices, caries behavior in the 
deciduous dentition, through exposure to fluoridated water.

\section{Methods \\ Design}

Aiming to analyze caries behavior in the deciduous dentition, through exposure or not to fluoridated water, two simultaneous crosssectional observational studies of the census type were performed. The primary data were obtained in november of 2014. The period considered for exposure or not to fluoridation of public water supply was from 2009 to 2014 (for at least Fiveyears). Two extremely similar cities were chosen, that differed only by the fluoridation or not of the public supply, in order to compare the behavior of caries in children under action or not in water fluoridation.

\section{Study area}

Among the brazilian municipalities that met and did not meet the criteria of exposure to fluoridation and whose social spaces fulfilled the requirement of similarity adopted in this research, practically identical in geographic, financial, social and cultural aspects, the municipalities were selected. Both met the criterion to be constituted in similar "social spaces" paired a priori, capable of generating population parameters obtained through two simultaneous censuses, directly comparable. ${ }^{16}$ The cities belong to southeastern Brazilian region, state of São Paulo, which had or not had correct and continuous fluoridation were Silveiras and São José do Barreiro, respectively. The distance between the cities is $47 \mathrm{~km}$ and no municipality "invades" them, which is quite common in large urban centers and their surrounding metropolitan areas. São José do Barreiro and Silveiras are also similar in the environmental and historical aspects. They have an extensive territory with large rural areas. Both were founded at the end of eighteenth century, being old areas of coffee cultivation, rich cities in the eighteenth and nineteenth centuries, lost economic relevance and became impoverished municipalities in the twenty-first century with economic and social dynamics in the commerce, agriculture and tourism.

\section{Study participants}

With the objective of analyzing the behavior of caries in deciduous dentition, through exposure or not to water fluoridation, whose populations have universal access to fluoridated dentifrices, all children of 5 and 6years old were examined in both municipalities $(\mathrm{N}=233)$. A group of 149 children was exposure and 84 was not exposure to fluoridated water. The criterion for individual exposure to fluoridated water was to reside, for at least 5years (from 2009 to 2014) in the same address. All children examined daily used fluoridated dentifrice.

\section{Study tools and procedures}

The calibration technique of the 4 field teams, composed by dentists and annotators, was performed with Kappa interexaminer $(\mathrm{K}=0.97$ 0.98 ) and intraexaminer ( $\mathrm{K}=0.98-1.00)$, considered to be optimal. ${ }^{23}$ Oral examinations were performed in all school units obeying the criteria of the World Health Organization for epidemiological surveys in oral health..$^{23}$ The teams made systematic returns to schools, according to the method, seeking to exhaust the possibilities of including all children. Losses were less than $2 \%$, mainly resulting from the explicit refusal from the parents and repeated absences from school. Thus, we set up the census aspect of this research.

\section{Study analysis}

Data processing was performed using the Epi-Info software. The experience and magnitude of dental caries in children exposed and not exposed to water fluoridation was evaluated using the dmft index. We measured the scaling of the difference in the prevalence between exposed and not exposed using the prevalence ratio (PR) and we tested the exposure-disease association Pearson's chi-square statistics.

\section{Ethical clearance}

The research was approved by the Brazilian National Ethics Committee with CAAE process 34299614.7.00005421.064944/2014 , recognized by the CEP/CONEP system, before the beginning of the field stage, according to Brazilian regulations. ${ }^{24}$

\section{Results}

The value of the dmft index was $2.74(\mathrm{SD}=3.50)$ for those exposed to fluoridated water and $4.17(\mathrm{SD}=3.50)$ for those not exposed (Table 1). Mode was 0.0 in both distribution and the median was 1.0 for those exposed and 4.0 for those not exposed. The amplitude of variation was 13 for those exposed and 12 for those not exposed. The coeficiente of variation was 1.28 for those exposed and 0.84 for those not exposed (Figure 1). The box plot shows the patterns of variability of the two populations. It shows that diferente magnitudes represented by the values of dmft index were not from aberrante values, the nonoccurrence of outliers (Figure 1). The percentage of individuals without caries experience was $43 \%$ in those exposed and $31 \%$ in those not exposed. Already, the percentage of children with three or more caries was $36.2 \%$ in those exposed and $59.4 \%$ in those not exposed (Figure 2). Both those exposed and not exposed presented distributions marked by moderate internal inequality (Figure 3 ). The Lorenz curves for those exposed and not exposed corresponded to Gini Coefficients of 0.6574 and 0.4835 , respectively. We observed a curve for those exposed, greater inequality in the distribution of the disease, indicating more polarization, compared to the curve corresponding to those not exposed. This characteristic of the distributions of $\mathrm{dmft}$ values in the exposed and no exposed populations is also expressed in the mean values of the $\mathrm{dmft}$ index. The PR between those not exposed and those exposed ( $\mathrm{PR}=\mathrm{NE} / \mathrm{E})$ was 1.21 , indicating little expressiveness in prevalence difference. The chi-square value $(2.777$; $\mathrm{p}=0.96, \alpha=5 \%$ ) indicated that the prevalence difference cannot be attributed to the exposure to the preventive measure.

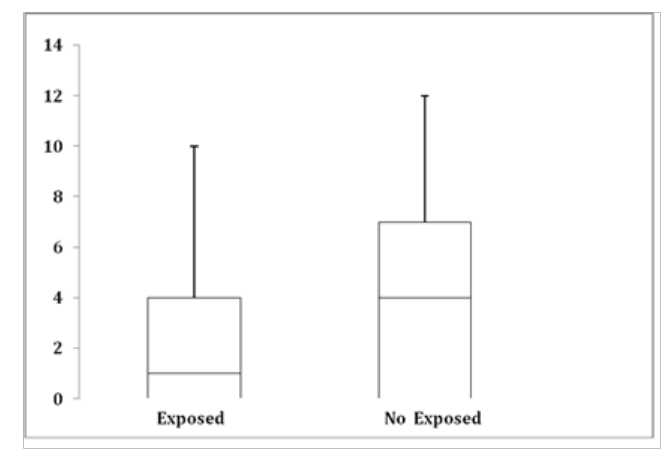

Figure I Box Plot of the distribution of the values of dmft index, in children aged 5 and 6years, according to exposure to fluoridated water. Silveiras (with fluoridation) and São José do Barreiro (without fluoridation), state of São Paulo, Brazil, 2014. 


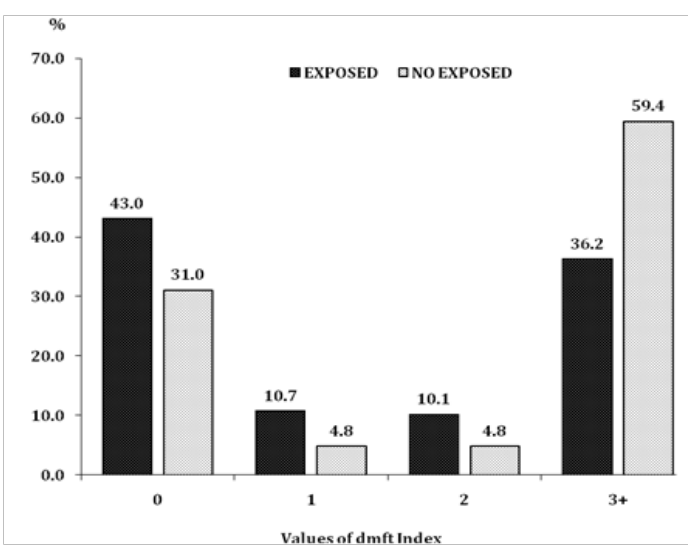

Figure 2 Percentage distribution of the values of the dmft index, in children aged 5 and $6 y$ years, according to exposure to fluoridated water. Silveiras (with fluoridation) and São José do Barreiro (without fluoridation), state of São Paulo, Brazil, 2014.

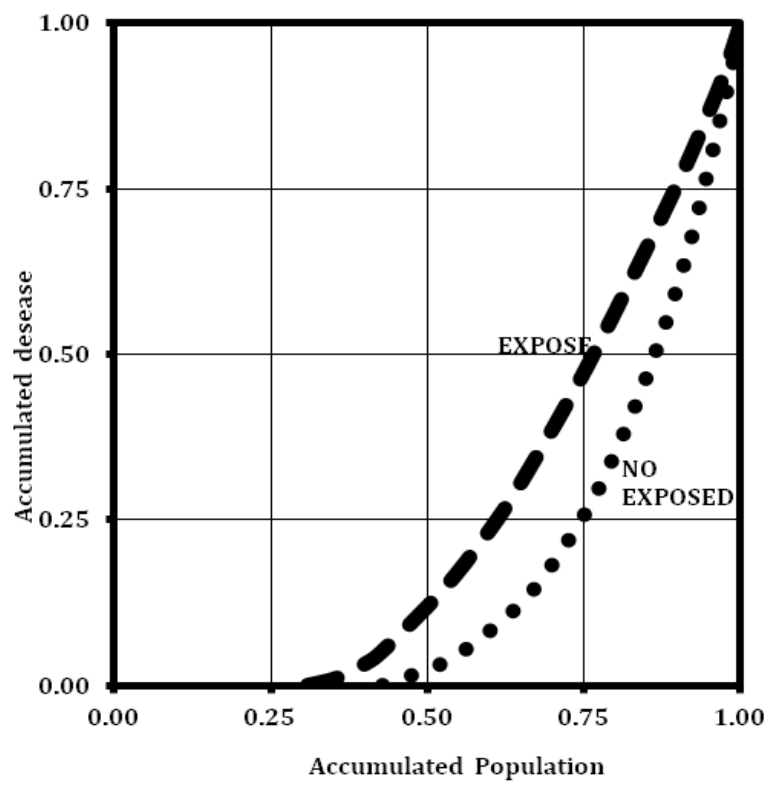

Figure 3 Lorenz curves for load distributions of dental caries in children aged 5 and 6years, according to exposure to fluoridated water. Silveiras (with fluoridation) and São José do Barreiro (without fluoridation), state of São Paulo, Brazil, 2014.

\section{Discussion on findings}

This research is the first one carried out in Brazil and Latin America, that consists of two epidemiological population censures in children differentiated only according to exposure or not to public water fluoridation. In Latin America, including Brazil and the Caribbean, since the beginning of the $21^{\text {st }}$ century, it was found that more than $50 \%$ of children aged 5 and 6years are affected by the dental caries, the major public oral health challenge in these regions. The study is made up of two simultaneous cross-sectional studies, that have limitations. One is that, they observe one moment in time and cannot, therefore, measure the time of exposure to variables that may be associated with the observed outcomes. The results demonstrate that eight out of ten deciduous decayed teeth are not treated in those not exposed to fluoridated water, the same proportion as the $80 \%$ of untreated decayed primary teeth recorded by the Brazilian Oral Health Survey, 2010. Those exposed to fluoridated water this proportion is $67 \%$. However, it is noteworthy that in both populations analyzed, the great majority of decayed primary teeth remain without receiving any dental treatment, in 2014 (Table 1). These data reiterate the challenge of dental caries without treatment, especially in children.

Table I dmft index and components for 5 and 6years old chindren, according to exposure to water fluoridation. Silveiras (with fluoridation) and São José do Barreiro (without fluoridation), state of São Paulo, Brazil, 2014.

\begin{tabular}{lllllll}
\hline \multirow{3}{*}{ Index } & \multicolumn{6}{l}{ Exposure to fluoridated water } \\
\cline { 2 - 7 } & \multicolumn{3}{l}{ Yes $(n=149)$} & \multicolumn{4}{c}{ No $(n=84)$} \\
\cline { 2 - 7 } Dmft & $\mathrm{N}$ & Average & $\%$ & $\mathrm{~N}$ & Average & $\%$ \\
\hline & 409 & 2.74 & 100 & 350 & 4.17 & 100 \\
\hline decayed & 273 & 1.83 & 66.8 & 285 & 3.39 & 81.3 \\
missing & 6 & 0.04 & 1.4 & 2 & 0.03 & 0.7 \\
filled & 130 & 0.87 & 31.8 & 63 & 0.75 & 18.0 \\
\hline
\end{tabular}

The median is 1.0 for those exposed and 4.0 for those not exposed, indicating the worst condition of the disease for those not exposed (Figure 1). Those exposed to water fluoridation $43.0 \%$ were free of caries, while those not exposed $31.0 \%$. At the most heavily loaded pole of the disease, $36.2 \%$ of those exposed to fluoridation of water have three or more teeth affected, while those not exposed $59.4 \%$ (Figure 2). These results point to the efficacy of water fluoridation as a preventive measure, and in a context of poverty and difficult access to dental services gains fundamental importance. The value (4.17) of $\mathrm{dmft}$ index obtained for those not exposed is $52 \%$ highter than the value (2.74) obtained for those benefited by water fluoridation, even though both children populations were exposed to the fluorides in toothpaste in these cities. This difference (52\%) represents a original information of great value in Brazilian situation, marked by important health inequalities. Such admission results from this research and the available knowledge about Brazilian demographic and health reality.

\section{Conclusion}

Public water fluoridation was identified as environmental variable to explain the lower magnitude of the $\mathrm{dmft}$ índex among those exposed to the measure. Exposure to fluoridated water implied a lower mean value of the $\mathrm{dmft}$ index at a level of $52 \%$, although in the presence of concomitant universal exposure to fluoride dentifrice.

Fluoridation of public water supply promotes relevant epidemiological effects in the Brazilian context, with health inequities, in which dental caries in primary teeth has remained a challenge for Oral Health not only in the country, but also throughout Latin America and the Caribbean.

\section{Acknowledgements}

None.

\section{Conflict of interest}

The author declares that there is no conflict of interest. 


\section{References}

1. Antunes JLF, Narvai PC, Nugent ZJ. Measuring inequalities in the distribution of dental caries. Community Dent Oral Epidemiol. 2004;32(1):41-48.

2. Fejerskov O. Changing paradigms in concepts on dental caries: consequences for oral health care. Caries Res. 2004;38(3):182-191.

3. Narvai PC, Frazão P, Roncalli AG, et al. Cárie dentária no Brasil: declínio, iniquidade e exclusão sócial. Rev Panam Salud Pública. 2006;19(6):385-393.

4. Antunes JLF, Narvai PC. Políticas de Saúde Bucal no Brasil e seu Impacto sobre as Desigualdades em Saúde. Revista de Saúde Pública. 2010;44(2):360-365.

5. Kassebaum NJ, Bernabé E, Dahiya M, et al. Global burden of untreated caries: a systematic review and metaregression. $J$ Dent Res. 2015;94(5):650-658.

6. Pitts NB, Evans DJ, Nugent ZJ, et al. The dental caries experience of 12 -year-old children in England and Wales. Surveys coordinated by the British Association for the study of Community Dentistry in 2000/2001. Community Dent Health. 2002;19(1):46-53.

7. Pitts NB, Boyles J, Nugent ZJ, et al. The dental caries experience of 5-years-old children in England and Wales (2003/4) and Scotland (2002/3). Community Dent Health. 2005;22(1):46-56.

8. Hashim R, Thomson WM, Ayres KM, et al. Dental caries experience and use of dental services among preschool children in Ajman, UAE. Int $J$ Paediatr Dent. 2006;16(4):257-262.

9. Gimenez T, Bispo BA, Souza DP, et al. Does the decline in caries prevalence of Latin America and Caribean children continue in the new century? Evidence from systematic review with meta-analysis. PLoS One. 2016;11(10): 0164903.

10. Traebert JL, Peres MA, Galesso ER, et al. Prevalência e severidade da cárie dentária em escolares de seis e doze anos de idade. Revista de Saúde Pública. 2001;35(3):283-288.

11. Antunes JLF, Peres MA, Mello TRC. Determinantes individuais e contextuais da necessidade de tratamento odontológico na dentição decídua no Brasil. Ciência \& Saúde Coletiva. 2006;11(1):79-87.
12. Antunes JLF, Ardenghi TM, Piovesan C. Desigualdades na prevalência de cárie dentária não tratada em crianças pré-escolares no Brasil. Revista de Saúde Pública. 2013;47(3):129-137.

13. Muller IB, Castilhos ED, Camargo MBJ, et al. Experiência de cárie e utilização do serviço público odontológico por escolares: estudo descritivo em Arroio do Padre, Rio Grande do Sul, 2013. Epidemiol Serv Saúde. 2015;24(3):759-770.

14. Camargo MBJ, Barros AJD, Frazão P, et al. Preditores da realização de consultas odontológicas de rotina e por problema em pré-escolares. Revista de Saúde Pública. 2012;46(1):87-97.

15. Feitosa S, Colares V. As repercussões da cárie precoce na infância na qualidade de vida de prés-escolares. Rev. Ibero-am Odontopediatr Odontol Bebê. 2003;6(34):542-548.

16. Barata RCB, Werneck GL (2011). Observação e registro dos fenômenos epidemiológicos: Tempo, espaço, indivíduos e populações. In: Almeida Filho NA, Barreto ML. Epidemiologia e Saúde; fundamentos, métodos e aplicações. Rio de Janeiro: Guanabara-Koogan, p. 1-147.

17. Cury JA. Uso do flúor e controle da cárie como doença. In: Baratieri LN, et al. Odontologia restauradora. São Paulo: Santos, 2001, p. 1-98.

18. Narvai PC, Frias AC, Fratucci MVB, et al. Fluoretação da água em capitais brasileiras no início do século XXI: a efetividade em questão. Saúde em Debate. 2014;38(102):562-571.

19. Nunn JF, Steele JG. Fluorides and dental caries. In: Murray JJ, editor. Prevention of oral disease. Oxford University Press. 2003;4:35-60.

20. Gunn AJR, Do L. Effectiveness of water fluoridation in caries prevention. Community Dentistry and Oral Epidemiology. 2012;40(2):55-64.

21. Zipporah IE, Worthington HV, Walsh T, et al. Water fluoridation for the prevention of dental caries. Cochrane Database of Systematic Reviews. 2015;6.

22. Kumar JV. Is water fluoridation still necessary? Advances in Dental Research. 2008;20(1):8-20.

23. WHO - World Health Organization. Oral health surveys: Basic methods. 4th ed. Switerzeland, 1997. p. 1-123.

24. Barbosa AS, Boery RNSO, Boery EN, et al. A Resolução 196/96 e o sistema brasileiro de revisão ética de pesquisas envolvendo seres humanos. Re. Bioética. 2011;19(2):523-542. 